\title{
Does the breeding performance differ between solitary and colonial breeding Red-throated Loons Gavia stellata in the core area of the Swedish population?
}

\author{
Skiljer sig häckningsutfallet mellan ensam- och kolonihäckande smålommar Gavia \\ stellata i artens svenska kärnområde?
}

\author{
BÖRJE DAHLÉN \& MATS O. G. ERIKSSON
}

\begin{abstract}
Most Red-throated Loons Gavia stellata are solitary breeders in small pools and provide fish prey to the chicks from larger waters at a distance seldom exceeding $10 \mathrm{~km}$. More rarely, several pairs nest together in colonies. We compared the breeding performance of solitary and colonial breeders in South-central Sweden during 2000-2016 (except for 2007). Annual productivity was 0.63 and 0.52 chicks per pair and year for solitary and colonial breeding pairs respectively, and mean percentage per year of broods with two chicks did not differ, $24 \%$ and $18 \%$ (no significant differences). Average hatching probability was the same, 0.576 and 0.581 over years. The average probability however, that at least one chick would be fledged was significantly higher among solitary
\end{abstract}

pairs, 0.915 and 0.731 respectively, although the overall probability of successful breeding did not differ, 0.530 and 0.443 . Thus, any benefit with reference to coloniality can be questioned. More likely, colonial breeding was a result of habitat selection, with a concentration of several nesting pairs within a relatively small area with a profitable foraging lake nearby.

Börje Dahlén, Strandvägen 6, 78235 Malung, Sweden; borje.dahlen@telia.com.

Mats O. G. Eriksson, MK Natur- och Miljökonsult, Tommeredsvägen 23, 43792 Lindome, Sweden; eriksson. tommered@telia.com.

Received 18 January 2016, Accepted 2 September 2016, Editor: Jonas Waldenström

Colonial breeding among birds, defined as an assemblage of nests within a limited area and with the primary source of food outside the territory, has been intensively studied in several bird species (e.g. Brown \& Brown 2001 for an overview). Nevertheless, it remains an elusive phenomenon which is hard to explain. With the development of the behavioural ecology approach to explain the evolution of various adaptations in terms of a balance between fitness-related benefits and costs during the 1970s, studies of coloniality were primarily focused on predation risk and finding food (e.g. Chapter 2 in Perrins \& Birkhead 1983 for an overview). Avoiding predation was thought to occur either actively by increased vigilance (several pairs of eyes see more than a few) and mobbing of predators, or passively by dilution (although a colony may attract predators, as long as the predation pressure does not increase in proportion to the number of nests in the colony, the risk for any individual to fall victim will decrease). With reference to obtaining food, colonies have been proposed to serve as 'information centres', where individual birds may benefit from observing and following conspecifics to assumed food resources. Over time however, the theoretical approach shifted from individual benefits to interpreting coloniality as the result of, or a by-product of, so called commodity selection with reference to the availability of e.g. habitats or mates (e.g. Danchin \& Wagner 1997, Wagner et al. 2000). Based on a comparative study including 320 bird species, colonial breeding has been proposed to be correlated with the absence of a feeding territory, breeding in aquatic habitats, and exposure to predators (Rolland et al. 1998).

The Red-throated Loon Gavia stellata fits into this categorisation in so far as it is linked to aquatic habitats, forages outside the breeding territory, and that nest predation is a key reason for breeding failure (e.g. Dickson 1993, Eberl \& Picman 1993, Dahlén \& Eriksson 2002, Rizzolo et al. 2014). However, it most often breeds solitarily with single pairs nesting in small pools, often smaller than 1 ha and rarely larger than 10 ha, and mostly without fish. Prey fish for the non-fledged chicks are caught from larger lakes with clear water, or at sea, with 
the travelling distance rarely exceeding $10 \mathrm{~km}$ (e.g. Eriksson 2010). Less often, several nesting Redthroated Loon pairs may group together in colonies (e.g. Chapter 11 in Lack 1968, Cramp \& Simmons 1977).

In this study, we compare the breeding success of solitary breeding pairs with pairs breeding in a colony in the same geographical region in Southcentral Sweden, in order to investigate if there is any indication of different breeding performance among solitary and colonial breeding pairs. No previous comparisons of this character, as far as we know, have been published with reference to the Red-throated Loon.

\section{Study area}

The study area is located in the County of Dalarna within the core area of the Swedish population of Red-throated Loon. Dalarna together with the neighbouring counties (Värmland, Örebro and
Västmanland) harbour a total of 470-600 pairs, or about one third of the total population in Sweden (data from Ottosson et al. 2012). Prey fish for the chicks are almost exclusively caught in nutrientpoor freshwater lakes with a dominance of smallsized cyprinid or salmonid fish (Eriksson 2006, Eriksson \& Paltto 2010).

The breeding performance of solitary breeding pairs was investigated in the same area as in a previous study of the target species in Malung-Sälen Municipality $\left(60^{\circ} 41^{\prime} \mathrm{N}, 13^{\circ} 43^{\prime} \mathrm{E}\right)$ in the County of Dalarna (Figure 1 in Dahlén \& Eriksson 2002). The area is approximately $1,820 \mathrm{~km}^{2}$, with a population of around 70 Red-throated Loon pairs that have been surveyed on an annual basis during the period 1991-2016. During 1991-2002, the surveys covered 130-150 pools or the majority of potential breeding sites, but after that the annual field surveys have been restricted to a smaller sample of 27-91 pools. The presence of a territory-holding pair has been recorded in at least one year in 99

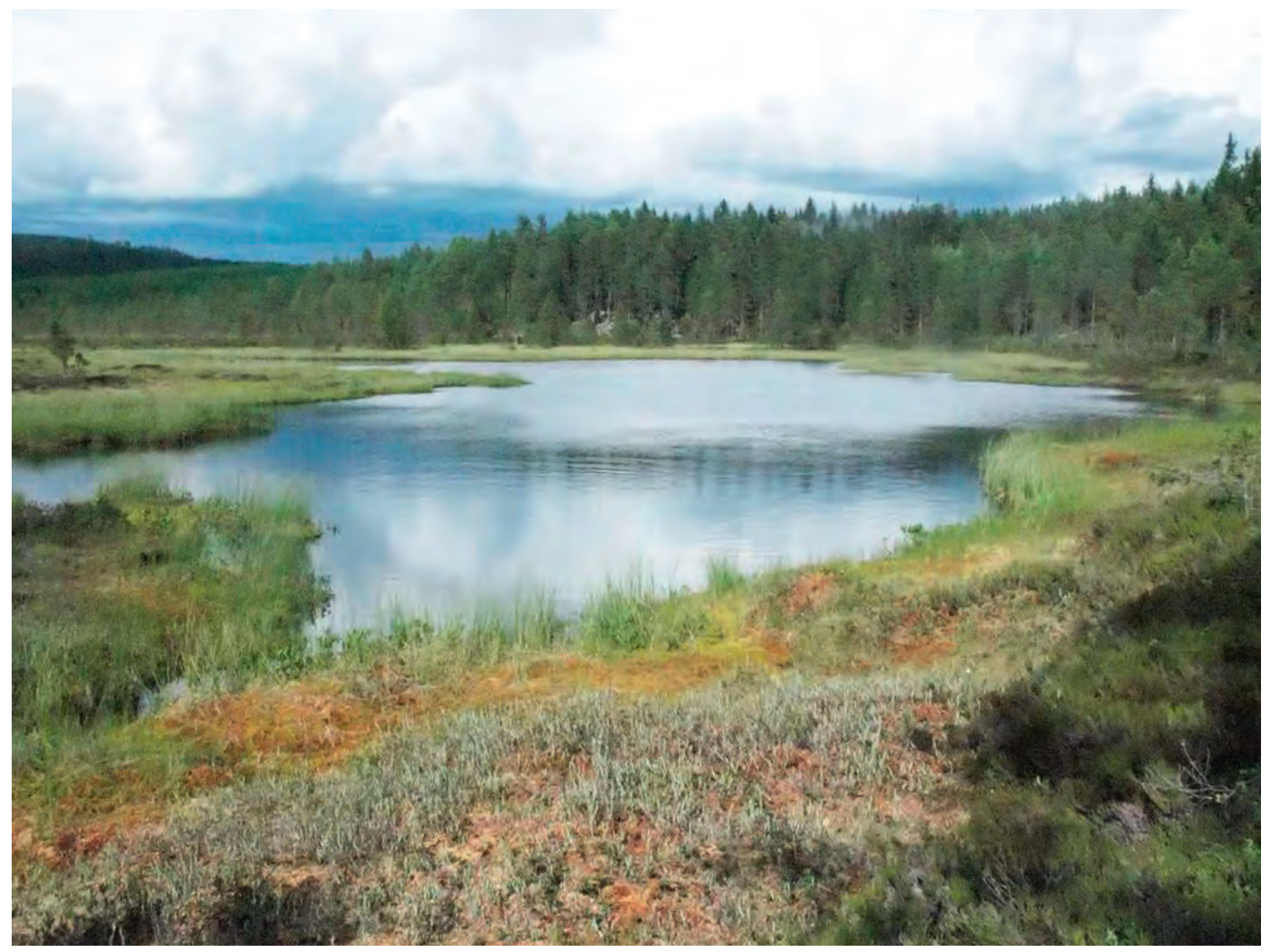

Figure 1. Breeding pool regularly used by a solitary Red-throated Loon Gavia stellata pair in the study area. Photo: Börje Dahlén.

Häckningstjärn som regelbundet nyttas av ett ensamhäckande smålomspar. Foto: Börje Dahlén. 


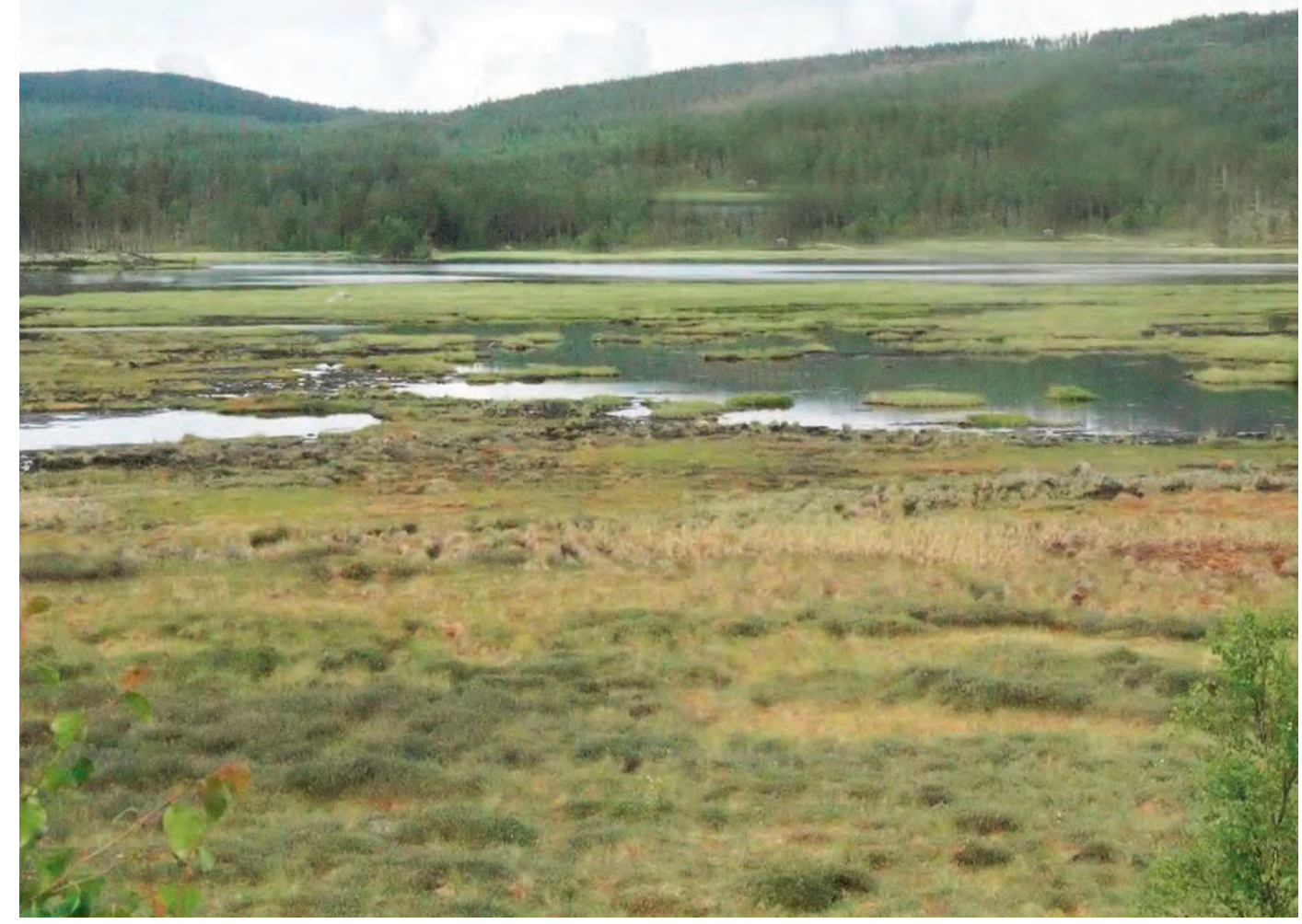

Figure 2. The Tisjökölen mire area, used by colonial breeding Red-throated Loons Gavia stellata, as viewed from the observation tower. Photo: Börje Dahlén.

Myrområdet Tisjökölen, vy från fågeltornet. Foto: Börje Dahlén.

pools (Figure 1 shows one of the sites). 15-20 nutrient-poor clear-water lakes are used for foraging, with distances ranging from less than $0.5 \mathrm{~km}$ to 4.6 $\mathrm{km}$ between breeding pools and foraging lakes. For the purpose of this study, results from the field surveys during the period 2000-2016 have been used, with the exception of 2007 when survey coverage was too poor.

In parallel, the breeding performance of a concentration of Red-throated Loons breeding at Tis-

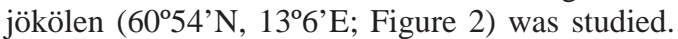
This is a mire site of ca $0.85 \mathrm{~km}^{2}$ and is located approximately $35 \mathrm{~km}$ northwest of the centre of the above described area (pages 120-122 in DOF 2005 for a further description). The Red-throated Loon population has been surveyed in the period 2000-2016 (except for 2007), and the number of pairs has fluctuated at around 20, making the colony at Tisjökölen the largest known concentration of breeding Red-throated Loon at a single site in Sweden. The distance between single nests can be as little as 30-40 meters, and 2-3 pairs may breed within the same pool. The birds catch fish prey for the chicks at Lake Tisjön, located immediately north of the mire area and at a distance of ca $1 \mathrm{~km}$ from the centre of the mire to the nearest shore of the lake.

Previous studies (Dahlén \& Eriksson 2002) indicate that the nest initiation in the study area is spread over a period of approximately six weeks, from mid-May until the end of June, although around half of the nests are initiated over a concentrated period of around ten days during early or mid-June. Around 15\% of failed clutches are followed by replacement clutches initiated from early June until mid-July. Very few chicks are thus hatched after the mid or end of August, when there is still a period of 2-3 months before icecover; i.e. freezing does not constitute a breeding constraint. 


\section{Methods}

Field surveys and assessment of breeding performance

For the study area with solitary breeding pairs, the field surveys followed the same methodology as in previous surveys in the same area (Dahlén \& Eriksson 2002), and assessments of the breeding performance were based on a sample from a larger population (see above under "study area"). Normally 2-4 visits at each breeding pool were required in order to get enough information for a reliable assessment of the breeding result. At the Tisjökölen site, surveys were made from an observation tower from where the majority of all potential breeding pools could be surveyed.

For both areas, the first visit during each season was done before or during the nesting period, in order to reduce the risk of biased estimates of the breeding performance due to undetected but failed breeding attempts. The timing of the last visit at each site was adjusted in order to follow the survival of chicks until they were classified as largesized: being more than half of the length the adult parent birds. A few breeding records, where it was not possible to acquire the full information to meet these requirements, were excluded in the assessments of breeding performance.

For the two breeding categories, the annual productivity was measured by calculating the mean number of large-sized chicks per nesting pair, e.g. that breeding was confirmed by finding a nest with eggs or an incubating bird. Despite the fact that the risk of not detecting breeding attempts that failed before hatching was minimised, it cannot be excluded that some figures may be a slight overestimate. The same approach was however, applied for solitary and colonial breeding pairs during the whole study period. It is thus most likely, that this potential error has not introduced any bias that might affect comparisons between sites and or over time.

Breeding success was assessed by calculating daily survival rates, using the Mayfield method (as presented by Beintema 1996), assuming that an event such as the start of incubation, hatching or failure occurred at the mid-point date between two successive visits to the breeding site. The analyses were split up into assessments of hatching success, i.e. the probability that a clutch would hatch, and brood rearing success, i.e. the probability that at least one chick would survive to fledge. We assumed an average incubation period of 28 days and a fledging period of 40 days, on the basis of handbook information (e.g. Cramp \& Simmons 1977, Barr et al. 2000) as well as unpublished data from voluntary-based surveys of the breeding performance in Sweden (Projekt LOM, http://www.birdlife.se). Broods were considered as lost, if chicks were last seen when smaller than half-grown, but not recorded at later visits at the same site, and fledged if the chicks were larger than half-grown when seen for the last time. This approach includes a risk that broods lost soon after hatching may have been overlooked and thus erroneously classified as a failure late during the incubation stage, resulting in an underestimate of the assessment of hatching success while brood rearing success might have been overestimated. Any impact on the interpretation of the results is elaborated upon in the discussion section.

Finally, we used the annual mean percentage of broods with two large-sized chicks to get an indication of the survival of chicks until fledged. Most loon pairs lay two eggs (Dahlén \& Eriksson 2002, with reference to the studied population) and the chicks' survival is primarily dependant on the parents' food provisioning success, as has been indicated for the Red-throated Loon (Okill \& Wanless 1990, Eberl \& Picman 1993, Ball 2004, Rizzolo et al. 2014) as well as for the Black-throated Loon Gavia arctica (Jackson 2003). For these calculations we included breeding attempts detected only during the chick rearing stage.

\section{Statistical analyses}

As only parts of the data set were normally distributed (as checked with the Shapiro-Wilk test, http:// scistatcalc.blogspot.se/2013/10/shapiro-wilk-testcalculator.html), non-parametric alternatives were used for the statistical analyses. Hence, comparisons between solitary and colonial breeding pairs were done by pairing of data for the same year for both categories by using the Wilcoxon's test for matched pairs, and temporal trends in the breeding performance were investigated by calculating the Spearman rank correlation coefficient $r_{s}$ (e.g. Fowler \& Cohen 1995; two-tailed significance levels presented).

\section{Results}

\section{Solitary breeding pairs}

The average annual productivity was 0.63 ( \pm S.D.0.16) large-sized chicks per pair and year for solitary breeding pairs (details in Figure 3). This 


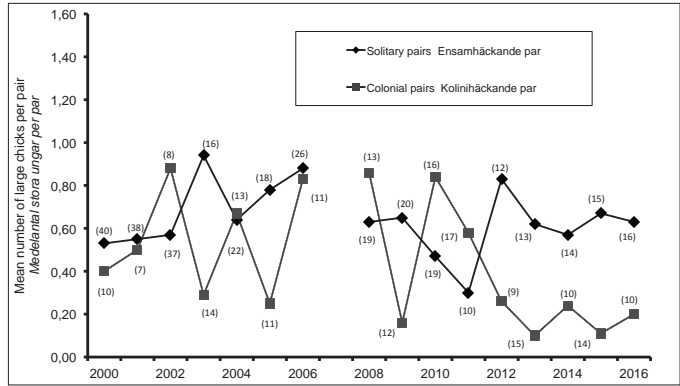

Figure 3. Mean number of large-sized chicks per pairs in solitary breeding and colonial breeding Red-throated Loon Gavia stellata pairs. Number of pairs included in the assessments is given in parenthesis.

Medelantal stora ungar per häckande par hos ensamhäckande och kolonihäckande smålommar. Antal par som ingår $i$ beräkningsunderlaget anges i parentes.

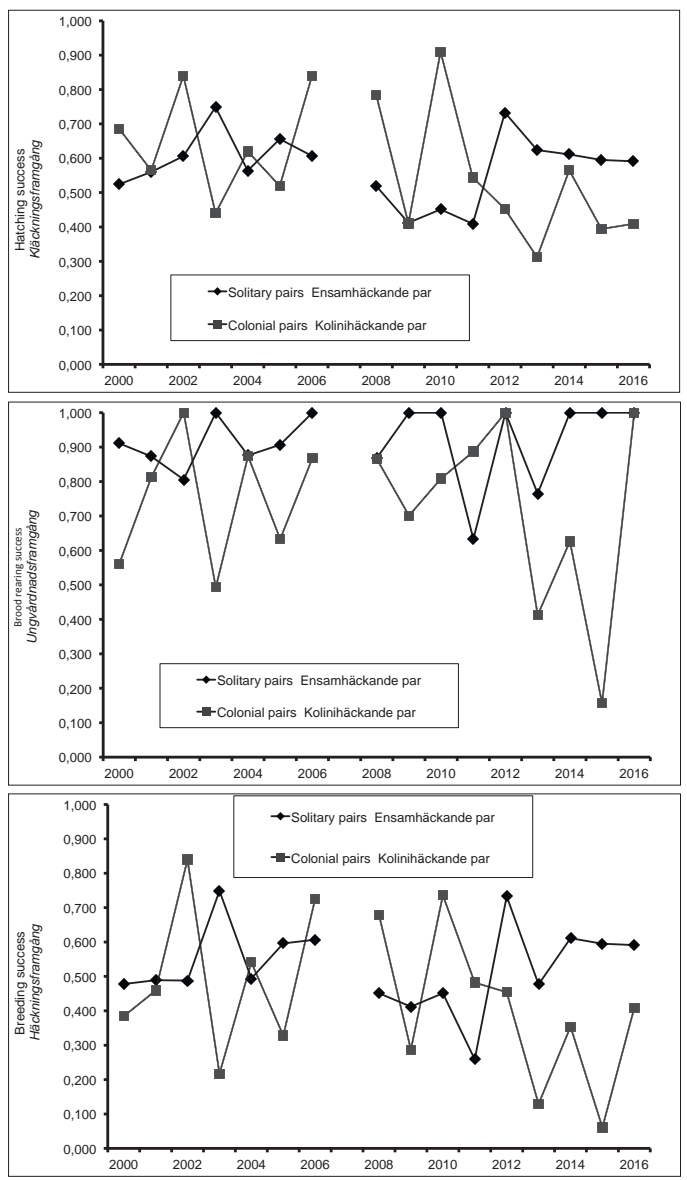

Figure 4. Breeding success in solitary breeding and colonial breeding Red-throated Loons Gavia stellata. Detailed data in Table 1.

Häckningsframgång hos ensamhäckande och kolonihäckande smålommar. Detaljdata i tabell 1.

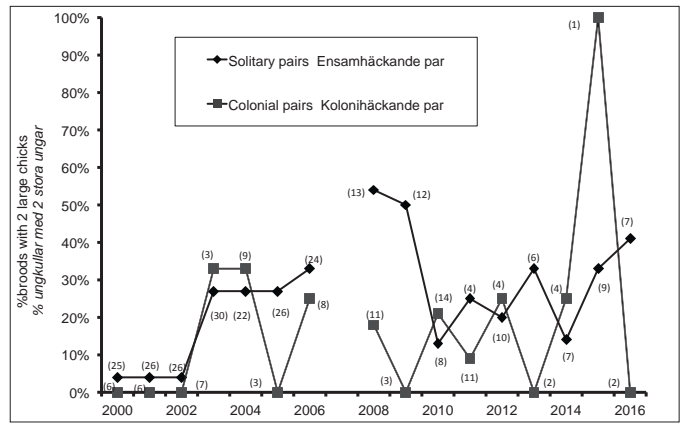

Figure 5. Percentage of broods with two large-sized chicks in solitary breeding and colonial breeding Red-throated Loon Gavia stellata pairs. Number of broods included in the assessments is given in parenthesis.

Procentandelen ungkullar med två stora ungar hos ensamhäckande och kolonihäckande smålommar. Antal ungkullar som ingår i beräkningsunderlaget anges i parentes.

figure is at the same level as recorded for Southcentral Sweden (Svealand and Dalsland) as a whole for the period 1994-2013 (Table 1 in Eriksson 2014). There was therefore no indication of any deviation from the overall breeding performance in a larger geographical context.

The mean hatching probability over years was 0.576 and the average probability that at least one chick in a brood would become fledged was assessed to be 0.915 over years, making an overall probability of successful breeding of 0.530 over years (Figure 4, details in Table 1a). The mean percentage over years of broods with two chicks was 24\% (details in Figure 5).

There were no indications of any temporal trends (Spearman $r_{\mathrm{s}}=-0.10$ for the mean number of chicks per pair, 0.04 for the hatching success, 0.33 for the brood rearing success, 0.07 for the overall breeding success, and 0.30 for the percentage of broods with two chicks, $\mathrm{N}=16$ years).

\section{Colonial breeding pairs}

For colonial breeding pairs the average annual productivity was 0.52 ( \pm S.D. 0.29$)$ large-sized chicks per pair and year (details in Figure 3), and although lower it was not statistically different from the results for solitary breeders (Wilcoxon's test for matched pairs, $\mathrm{p}=0.30$ ).

The mean hatching probability over years was 0.581 or the same as for solitary breeding pairs (Wilcoxon's test for matched pairs, $\mathrm{p}=1.00$ ) although, there was an indication of decline over the study period (Spearman $r_{\mathrm{s}}=-0.52,0.05<\mathrm{p}<0.10$ ). The average probability that at least one chick be- 


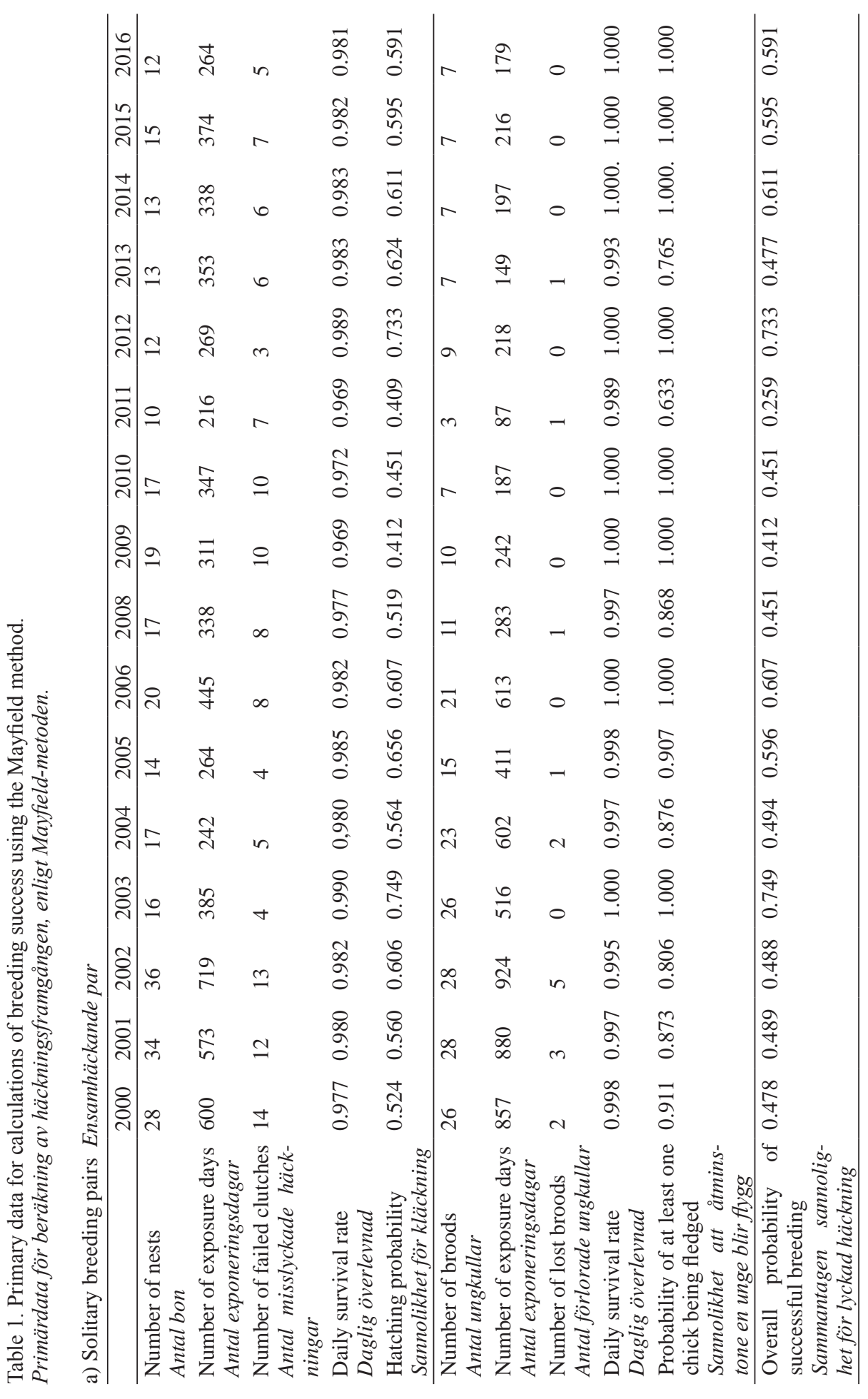




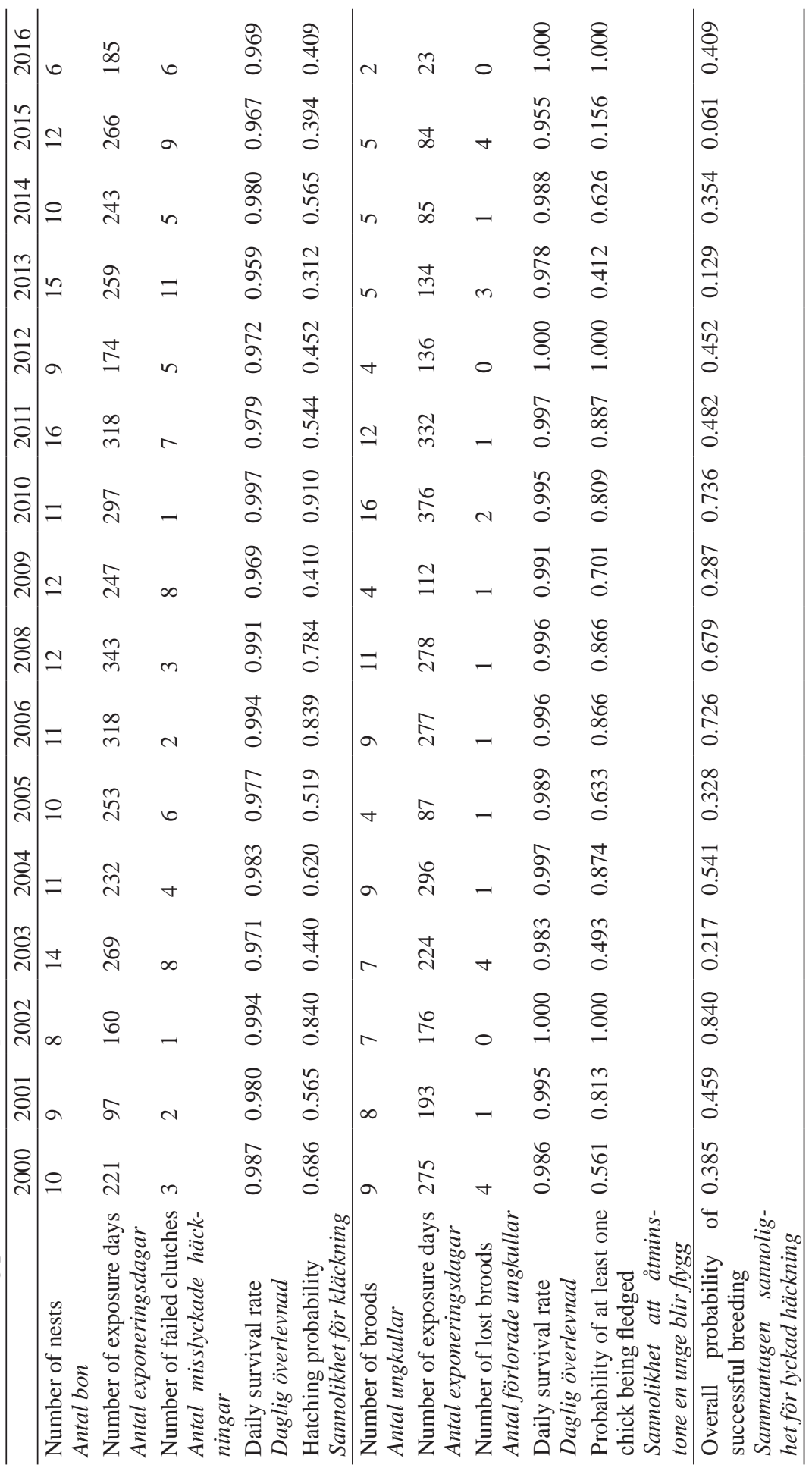



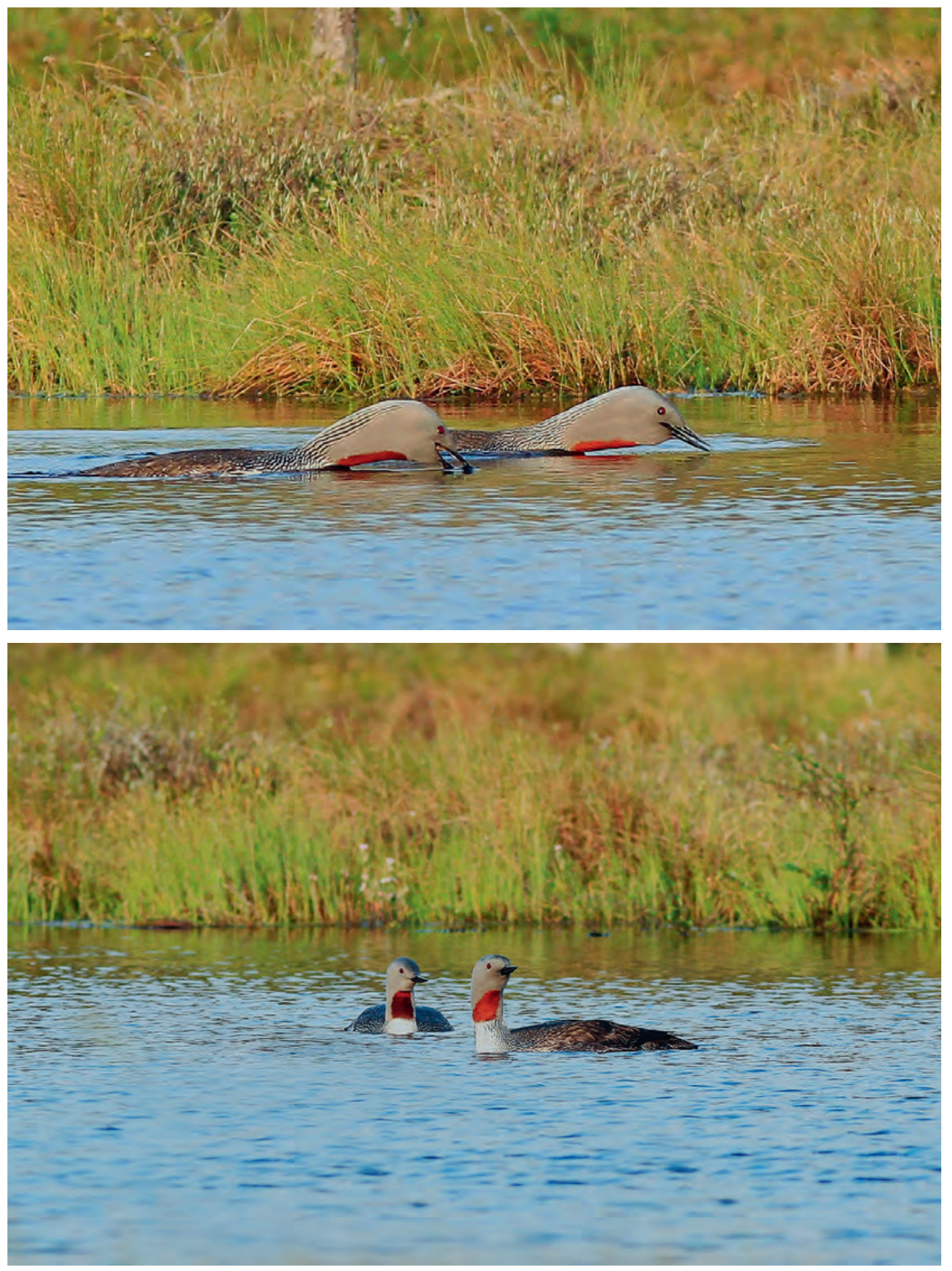

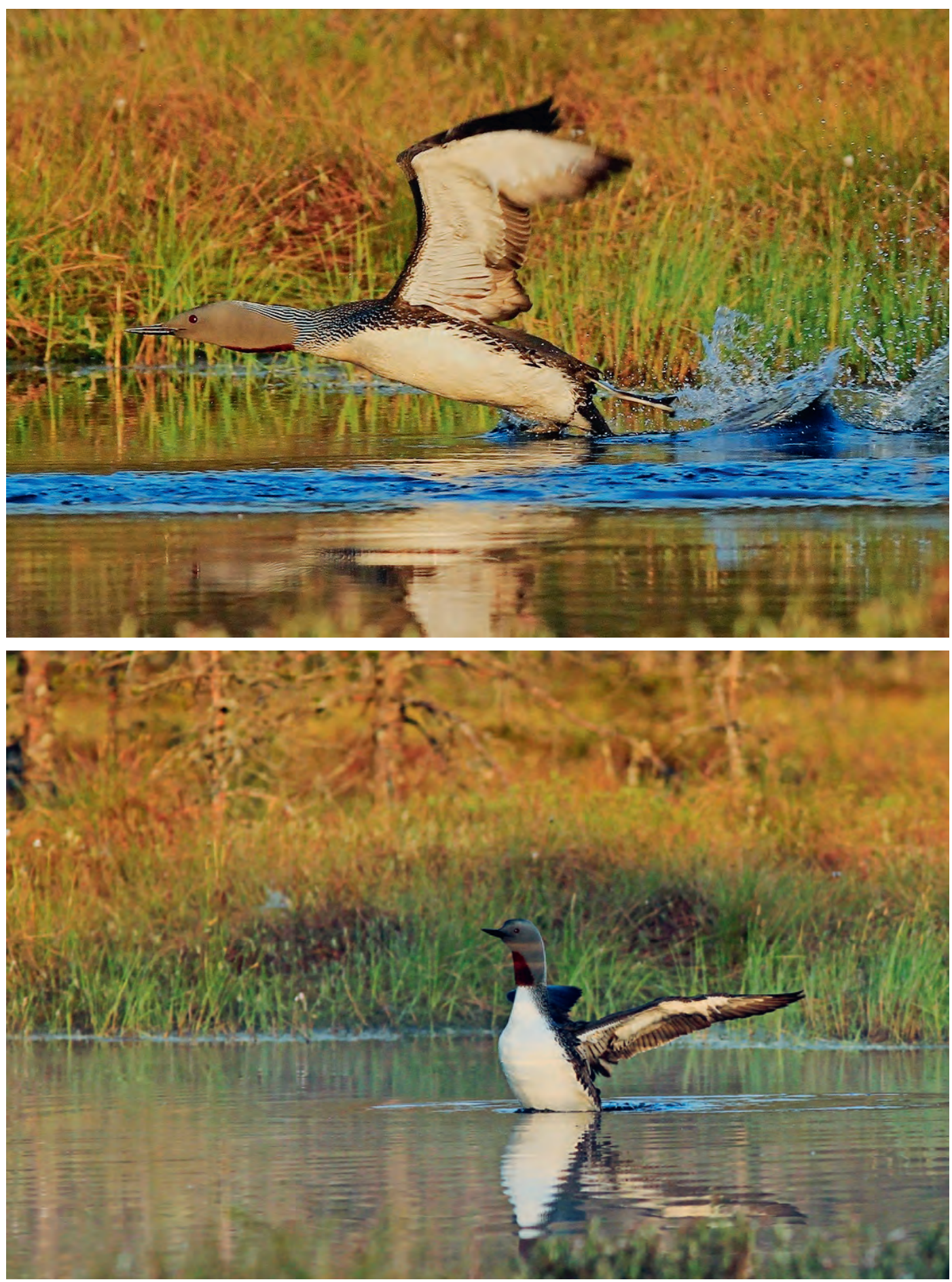

Red-throated loons in their breeding tarn. Photo: Christer Brostam.

Smålommar i häckningstjärnen. Foto: Christer Brostam. 
came fledged was assessed to be 0.731 and significantly lower than that for solitary breeding pairs (Wilcoxon's test for matched pairs, $\mathrm{p}=0.01$ ). Nevertheless, the overall probability of successful breeding was 0.443 over years and not significantly lower than for solitary breeding pairs (Wilcoxon's test for matched pairs, $p=0.28$, Figure 4 , details in Table 1b).

The mean percentage of broods with two chicks over years was 18\% (details in Figure 5) and did not differ from the solitary breeding pairs (Wilcoxon's test for matched pairs, $\mathrm{p}=0.29$ ).

As for solitary breeding pairs there were no indications of any temporal trends for the mean number of chicks per pair (Spearman $r_{s}=-0.40$ ), for the brood rearing success (Spearman $r_{s}=0.01$ ), the overall breeding success (Spearman $r_{s}=-0.32$ ) or the percentage of broods with two chicks (Spearman $\mathrm{rs}=0.22, \mathrm{~N}=16$ years).

Fluctuations in breeding performance between years were not synchronized between solitary and colonial breeding pairs (Spearman $\mathrm{rs}=-0.17$ with reference to the mean number of chicks per pair, -0.30 for the hatching success, -0.17 for the brood rearing success, -0.26 for the overall breeding success, and 0.29 for the percentage of broods with two chicks, $\mathrm{N}=16$ years). There was thus no indication that any external factor influenced the breeding performance in a similar way for both categories.

\section{Discussion}

Coloniality has been an attractive field of research, not least as breeding in colonies includes a balance between fitness benefits and costs, and over the years various predictions derived from the theoretical framework have been investigated in field studies and experiments, spanning a large number of species. But results are far from unambiguous or clear-cut, indicating that breeding in colonies may be adaptive for a variety of reasons and that there are not any simple or universal factors behind its evolution (e.g. Danchin \& Wagner 1997, Brown \& Brown 2001).

For the Red-throated Loon population in this study, the breeding performance was not different between the pairs breeding solitarily and those breeding in the Tisjökölen colony. The average annual productivity was 0.63 and 0.52 large chicks per pair and year respectively, with the reservation that slightly overestimated but still comparable figures cannot be excluded, even if the risk of not detecting breeding attempts that failed before hatching was minimised.
The percentage of broods with two chicks was similar for both categories at $24 \%$ and $18 \%$, respectively, which indicates that the survival of chicks until fledged was the same. Assuming that the chicks' survival to a large extent is related to the parents' success in providing them with food, in line with results from previous studies both on Red-throated Loon (Okill \& Wanless 1990, Eberl \& Picman 1993, Ball 2004, Rizzolo et al. 2014) and Black-throated Loon (Jackson 2003), our results did not indicate any difference between pairs breeding solitarily and colonially with reference to foraging success.

For both solitary and colonial breeding pairs, the probability of a successful breeding outcome was similar at 0.530 and 0.443 , respectively. Average hatching probability over years was the same at 0.576 and 0.581 , respectively, while the probability that at least one chick would be fledged was significantly lower for pairs breeding colonially at 0.731 compared to 0.915 for solitary breeding pairs. Nevertheless, the overall breeding success did not differ between the two categories and a likely reason for this is that most breeding failures occurred before hatching, as has been shown to apply for the studied population (Dahlén \& Eriksson 2002) as well as elsewhere (e.g. Eberl \& Picman 1993), and with predation being the main reason. So although there is a risk that chicks lost soon after hatching might have been overlooked, the indication of lower hatching success in comparison to brood rearing success was nevertheless expected with reference to previous results from various studies.

The lower brood rearing success among the colonial breeding pairs can hardly be related to food provision by the parents, as there was no indication of a different percentage of broods with two large-sized chicks. Furthermore, it does not seem as the pairs breeding in the Tisjökölen colony benefited from any lower predation pressure compared with the pairs breeding solitarily. Hatching probability was the same for both categories and previous studies (referred to above) have indicated that predation is the main reason for failures during the incubation period. Rather, it might be speculated if the concentration of breeding pairs and chicks in a limited area attracted predators, and that this might explain the indication of decline in hatching success as well as the lower brood rearing success among the colonial breeding pairs. Indeed, anecdotal information from field visits at the Tisjökölen site indicates that low breeding success in single years could be related to the presence of e.g. Eurasian Eagle Owl Bubo bubo, Western Marsh Harrier 

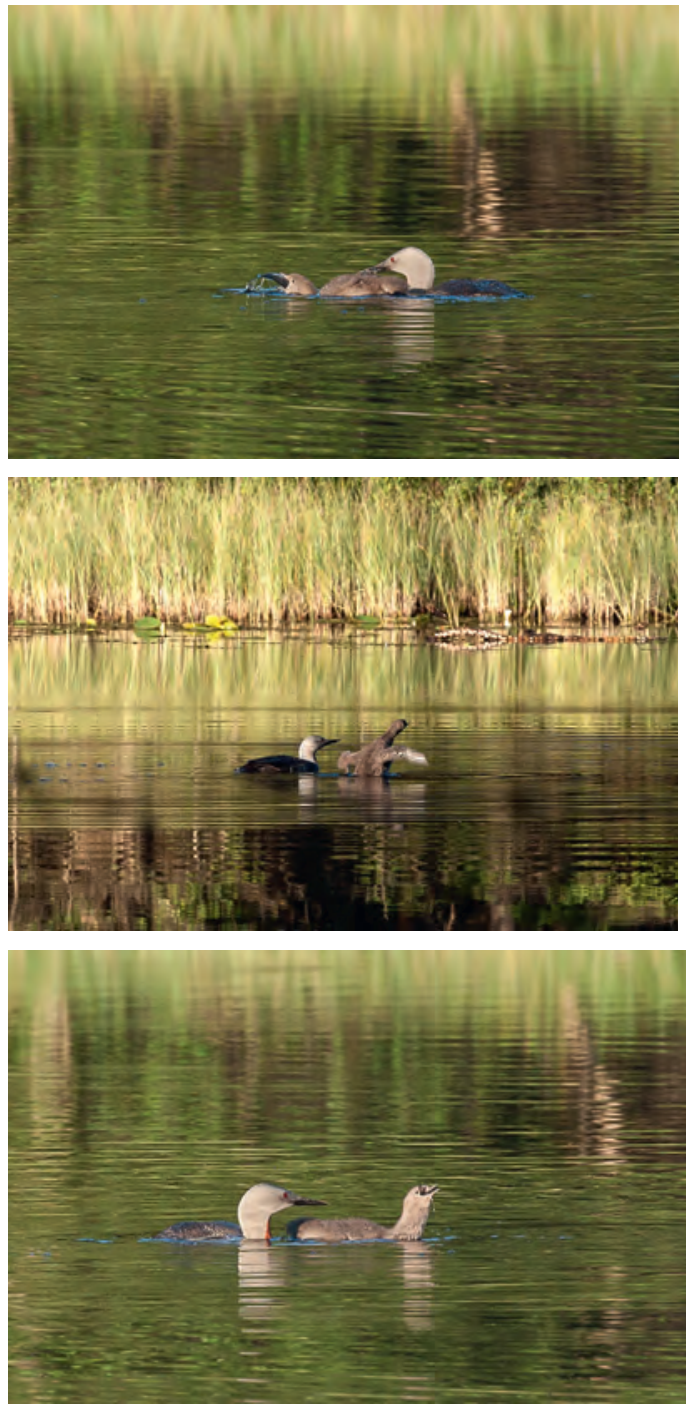

Red-throated Loon feeding young in the breeding tarn with a fish that has been collected in a clear-water lake at some distance. Photo: Kristina Eriksson.

Smålom matar unge i häckningstjärnen med fisk som hämtats i klarvattensjö på visst avstånd.
Circus aeruginosus or Red Fox Vulpes vulpes. In addition, there are no observations of any cooperative defence against predators by Red-throated Loons breeding at Tisjökölen, while this was recorded at the site for e.g. Northern Lapwing Vanellus vanellus and Mew Gull Larus canus against Red Fox. This is in line with previous findings suggesting that coloniality may attract predators rather than reduce the risks of predation (e.g. Varela et al. 2007).

For the Red-throated Loon, and bearing in mind that rigorous field experiments designed in order to test any hypotheses from current theory are lacking, it seems that habitat requirements per se determined the selection of breeding sites. Both kinds of habitats required for breeding, e.g. small pools with quagmire shores and freshwater lakes harbouring prey fish, such as small-sized cyprinid or salmonid fish are common elements in the coniferous forest landscape of Scandinavia, but a combination of both at a distance short enough for transporting fish to the chicks may be less common. Therefore, individual pairs do not avoid nesting with conspecifics where a concentration of potential nest-sites is located within a limited area and with profitable foraging waters at a close distance, if the expected breeding outcome is neutral in comparison to solitary breeding at a small and isolated pond. Thus, colonial breeding in the Red-throated Loon is most likely a result of commodity selection.

The result of this study is consistent with what has been found to apply for Red-necked Grebe Podiceps grisegena, another water-bird species that exhibits both solitary and colonial breeding. For this species, coloniality has been shown to be linked to the availability of quite rare high-quality habitats rather than any benefits of breeding in close vicinity to conspecifics (Sachs et al. 2007).

\section{Acknowledgments}

This study has been carried out within the framework of voluntary-based surveys of the breeding performance of Black-throated Loon and Red-throated Loon in Sweden, Projekt LOM; http://birdlife.se. The Alvin Fund and the Swedish section of the World Wildlife Fund (WWF Sverige) have given financial support in individual years. Two referees gave valuable comments and remarks on a previous draft. 


\section{References}

Barr, J.F., Eberl, C. \& McIntyre, J.W. 2000. Red-throated Loon (Gavia stellata). In: Poole, A \& Gills F, (eds.) The Birds of North America No. 513. The Academy of Natural Sciences, Philadelphia, and The American Ornithologists' Union, Washington D.C; http://bna.birds.cornell.edu/bna/ species/513/articles/introduction.

Ball, J.R. 2004. Effects of parental provisioning and attendance on growth and survival of Red-throated Loon prefledglings: A potential mechanism linking marine regime shifts to population change. M.Sc. thesis, Simon Fraser University, Burnaby, British Columbia; http://summit.sfu. ca/item/4829.

Beintema, A.J. 1996. Inferring nest success from old records. Ibis 138: 568-570.

Brown, C.R. \& Brown, M.B. 2001. Avian coloniality. Progress and problems. Pages 1-83 in Nolan Jr, V. \& Thompson, C.F. (eds.) Current Ornithology Volume 16. Kluwer Academic/Plenum Publishers, New York.

Cramp, S. \& Simmons, K.E.L. (eds.) 1977. The birds of the Western Palearctic. Volume 1. Oxford University Press, Oxford.

Danchin, E. \& Wagner, R.H. 1997. The evolution of coloniality: the emergence of new perspectives. Trends in Ecology and Evolution 12: 342-347; http://www.researchgate. net/publication/49758472_The_Evolution_of_Coloniality_the_Emergence_of_New_Perspectives.

Dahlén, B. \& Eriksson, M.O.G. 2002. Breeding biology of the Red-throated Diver Gavia stellata in the core area of the Swedish population. Ornis Svecica 12: 1-33; in Swedish, summary in English.

Dickson, D.L. 1993. Breeding biology of Red-throated Loon in the Canadian Beaufort Sea Region. Arctic 46: 1-7; http://arctic.journalhosting.ucalgary.ca/arctic/index.php/ arctic/article/view/1315/1340.

DOF 2005. Fågellokaler i Dalarna, $1^{\text {st }}$ ed. Dalarnas Ornitologiska Förening, Ludvika. http://online.pubhtml5.com/lfzt/ jidd/\#p=1.

Eberl, C. \& Picman, J. 1993. Effect of nest-site location on reproductive success of Red-throated Loons (Gavia stellata). Auk 110: 436-444; https://sora.unm.edu/sites/default/files/journals/auk/v110n03/p0436-p0444.pdf.

Eriksson, M.O.G. 2006. Breeding success of the Red-throated Diver Gavia stellata in relation to water chemistry and composition of the fish stocks in different fishing lakes. Ornis Svecica 16: 211-231; in Swedish, summary in English.

Eriksson, M.O.G. 2010. Storlommen och smålommen i Sverige - populationsstatus, hotbild och förvaltning. Sveriges Ornitologiska Förening, Stockholm och Svenska LOM-föreningen / Projekt LOM, Göteborg; http://www. projekt-lom.com/LOM-rapporten.pdf.

Eriksson, M.O.G. 2014. Projekt LOM 20 år - 1994-2013. Pages 33-47 in SOF 2014. Fågelåret 2013. Sveriges Ornitologiska Förening, Stockholm.

Eriksson, M.O.G. \& Paltto, H. 2010. Water chemistry and the composition of fish stocks in the breeding lakes of Blackthroated Diver Gavia arctica, and a comparison with the fishing lakes of Red-throated Diver Gavia stellata. Ornis Svecica 20: 3-30; in Swedish, summary in English.

Fowler, J. \& Cohen, L. 1995. Statistics for Ornithologists. Second edition. BTO Guide No 22, British Trust for Ornithology.
Jackson, D. 2003. Between lake differences in the diet and provisioning behaviour of Black-throated Divers Gavia arctica breeding in Scotland. Ibis 145: 30-44; http://onlinelibrary.wiley.com/doi/10.1046/j.1474919X.2003.00119.x/abstract.

Lack, D. 1968. Ecological adaptations for breeding in birds. Methuen, London.

Okill, J.D. \& Wanless, S. 1990. Breeding success and chick growth of Red-throated Divers Gavia stellata in Shetland 1979-88. Ringing \& Migration 11: 65-72; http://www. tandfonline.com/doi/pdf/10.1080/03078698.1990.96739 63.

Ottosson, U., Ottvall, R., Elmberg, J., Green, M., Gustafsson, R., Haas, F., Holmqvist, N., Lindström, A., Nilsson, L., Svensson, M., Svensson, S. \& Tjernberg, M. 2012. Fåglarna i Sverige - antal och förekomst. Sveriges Ornitologiska Förening, Halmstad.

Perrins, C.M. \& Birkhead, T.R. 1983. Avian Biology. Blackie, Glasgow \& London.

Rizzolo, D.J., Schmutz, J.A., McCloskey, S.E. \& Fondell, T.F. 2014. Factors influencing nest survival and productivity of Red-throated Loons (Gavia stellata) in Alaska. Condor 116: 574-587; https://www.researchgate.net/ publication/274698384_Factors_influencing_nest survival_and_productivity_of_Red-throated_Loons_Gavia_ stellata_in_Alaska.

Rolland, C., Danchin, E. \& de Fraipont, M. 1998. The evolution of coloniality of birds in relation to food, predation, and life history traits: a comparative analysis. American Naturalist 151: 514-529; http://www.ckwri.tamuk.edu/ fileadmin/tpl/misc/Rolland_C_1998.pdf.

Sachs, J.L., Hughes, C.R., Nuechterlien, G.L. \& Buitron, D. 2007. Evolution of coloniality in birds: a test of hypotheses with the Red-necked Grebe (Podiceps grisegena). Auk 124: 628-642; http://aoucospubs.org/doi/ pdf/10.1642/0004-8038\%282007\%29124\%5B628\%3AE OCIBA\%5D2.0.CO\%3B2

Varela, S.A.M., Danchin, E. \& Wagner, R.H. 2007. Does predation select for or against avian coloniality? A comparative analysis. Journal of Evolutionary Biology 20: 1490-1503; http://onlinelibrary.wiley.com/doi/10.1111/ j.1420-9101.2007.01334.x/pdf.

Wagner, R.H., Danchin, E., Boulinier, T. \& Helfenstein, F. 2000. Colonies as byproducts of commodity selection. Behavioral Ecology 11: 572-573; http://beheco.oxfordjournals.org/content/11/5/572.full.pdf+html.

\section{Sammanfattning}

Kolonihäckning brukar definieras som en ansamling av bon inom ett begränsat område, i kombination med att de viktigaste födokällorna ligger utanför reviret. Företeelsen har varit föremål för ett mycket stort antal undersökningar och har innefattat många olika arter, men det har visat sig vara svårt att hitta några generella förklaringar. Inom ramen för beteendeekologins framväxt under 1970-talet utvecklades ett teoribygge kring tänkbara för- och nackdelar och med fokus på risker för predation och förutsättningarna att hitta föda. 
Genom att häcka i kolonier kan vaksamheten mot predatorer bli mer effektiv - flera par ögon ser mer än två. Visserligen kan en koloni attrahera predatorer, men om predationsrisken inte ökar i proportion till kolonins storlek uppstår en utspädningseffekt och risken för varje enskilt bo kan antas minska. Kolonier har också föreslagits fungera som informationscentra; genom att observera och följa sina artfränder kan födosöket förmodas bli mer effektivt för egen del. Men över åren har den teoretiska ansatsen skiftat fokus från individuella fördelar till att tolka kolonihäckande i termer av en mer passiv effekt eller biprodukt av t.ex. habitatval eller sexuell selektion. Sammantaget har kolonihäckning bedömts vara vanligast bland vattenlevande fågelarter och kopplad till bl.a. avsaknad av ett födosöksrevir och hög predationsrisk.

Smålommen passar in i mönstret såtillvida att den är knuten till vattenmiljöer, födosöket sker utanför häckningsreviret och bopredation är en viktig orsak till misslyckade häckningar. Vanligast är att enstaka par häckar vid småsjöar och tjärnar som ofta saknar fisk. Bytesfisk till ungarna hämtas i större klarvattenssjöar eller i havet upptill ett avstånd på ungefär $10 \mathrm{~km}$, sällan längre, och med preferens för fiskevatten med småvuxna bestånd av mört- eller laxartad fisk. Men det förekommer också att flera par ibland häckar tillsammans i koloniartade ansamlingar.

I den här studien jämförs häckningsutfallet hos ensamhäckande smålommar i ett ungefär $1820 \mathrm{~km}^{2}$ stort undersökningsområde omfattande ungefär 70 par i Malung-Sälens kommun i Dalarna med en koloni belägen på Tisjökölen (Figur 2) som är ett ungefär $0,85 \mathrm{~km}^{2}$ stort myrområde med 20 -talet smålomspar. Oss veterligt har ingen liknande jämförelse gjorts tidigare och med avseende på smålommen.

\section{Metodik}

Vad gäller de ensamhäckande smålomsparen bedömdes häckningsutfallet genom att tänkbara häckningsplatser besöktes vid 2-4 tillfällen under häckningssäsongen för att få tillräckligt underlag för att bedöma häckningsresultatet. Vid Tisjökölen kunde huvuddelen av tänkbara häckningsgölar i myrområdet observeras från ett fågeltorn.

Häckningsutfallet bedömdes genom att beräkna medelantalet stora ungar per häckande par. Med "stora" ungar avsågs ungar som blivit minst halvvuxna. Vidare bedömdes häckningsframgången med den s.k. Mayfield-metoden, med separata beräkningar av kläckningsframgången (= sannolik- heten för kläckning) och ungvårdnadsframgången (= sannolikheten att åtminstone en unge blir flygg). Slutligen användes procentandelen ungkullar med två stora ungar som en indikation på ungarnas överlevnad tills de blivit flygga och under antagandet att ungarnas överlevnad primärt är beroende på hur föräldrafåglarna lyckas med att förse ungarna med fiskbyten (vilket i tidigare undersökningar har visat sig gälla för både smålommen och storlommen).

\section{Resultat}

På basis av data från 16 år, 2000-2016 (med undantag för 2007), kan resultaten sammanfattas, som följer:

- Ungproduktionen var i medeltal 0,63 stora ungar per par och år för ensamhäckande par och 0,52 för kolonihäckande par (detaljer i Figur 3, skillnaden är inte statistiskt signifikant). Resultatet ligger på samma nivå som för Svealand (och Dalsland) i övrigt.

- Sannolikheten för kläckning var densamma för ensamhäckande och kolonihäckande par, i medeltal 0,576 respektive 0,581 per år, medan ungvårdnadsframgången var högre för ensamhäckare jämfört med kolonihäckande par, i medeltal 0,915 respektive 0,731 per år. Men den sammanräknade häckningsframgången låg på ungefär samma nivå, i medeltal 0,530 respektive 0,443 per år för ensamhäckande och kolonihäckande par (Figur 4, detaljer i Tabell 1).

- Procentandelen ungkullar med två stora ungar var likartad, i medeltal $24 \%$ per år för ensamhäckande par och $18 \%$ för kolonihäckande (detaljer i Figur 5).

Det fanns en indikation på att häckningsframgången för kolonihäckade par försämrats, men därutöver noterades inga tidstrender i häckningsutfallet, vare sig för ensamhäckande eller kolonihäckande par. Variationerna i häckningsutfallet var inte synkroniserade, så det fanns ingen indikation på att externa faktorer har påverkat ensam- och kolonihäckande par på ett likartat sätt.

\section{Diskussion}

Det fanns inga indikationer på skillnader i häckningsutfallet eller att kolonihäckning skulle vara kopplad till någon fördel som kan mätas i termer av ungproduktion. Det faktum att procentandelen ungkullar med två stora ungar var densamma antyder att det inte var någon skillnad i ungarnas överlevnad tills de blivit flygga och således inte heller 
vad gäller föräldrafåglarnas möjligheter att finna bytesfisk till ungarna. Det är alltså inte troligt att kolonihäckningen har innefattat någon fördel med hänsyn till förutsättningarna för födosöket.

Sannolikheten för ett lyckat häckningsutfall var likartad och ungefär hälften av häckningarna lyckades i den meningen att åtminstone en unge blev flygg. Kläckningsframgången var lägre än ungvårdnadsframgången och nästan identiskt lika i de båda grupperna. Även i tidigare undersökningar har man noterat att de flesta av de misslyckade häckningarna överges under ruvningsstadiet och att bopredation är en av de viktigaste orsakerna. Det fanns alltså ingen indikation på kolonihäckningen inneburit någon fördel $\mathrm{i}$ form av mindre predationsrisk. Snarare kan frågan lämnas öppen om ansamlingen av flera par inom ett begränsat område kan attrahera predatorer, såsom närvaro av t.ex. berguv, brun kärrhök eller räv enstaka år, och att detta kan ha bidraget till den lägre ungvårdnadsframgången bland kolonihäckande par. Det finns inte några observationer av att smålommar gemensamt har försvarat sig mot predatorer, medan detta har noterats både hos tofsvipa och hos fiskmås när en räv befunnit sig ute på myren.

Våra resultat pekar på att det torde vara häckningsmiljön i sig, snarare än någon specifik fördel av att häcka i en koloni tillsammans med artfränder som förklarar varför smålommen ibland häckar i koncentrationer med flera par inom ett begränsat område. De två miljöer som smålommen behöver för sin häckning, dvs. småsjöar eller tjärnar med gungflyartade stränder med lämpliga boplatser och klarvattenssjöar med goda bestånd av småvuxen lax- eller mörtartad fisk är var för sig ganska vanliga i det skandinaviska barrskogslandskapet. Men det är kanske mindre vanligt att de båda miljöerna förekommer tillsammans med inbördes avstånd som inte är för stora för att försvåra transporten av bytesfisk till ungarna. En gynnsam kombination av flera lämpliga boplatser inom ett begränsat område och med lämpliga fiskevatten på nära avstånd kan alltså vara anledning till att flera smålomspar ibland häckar tillsammans, under förutsättning att det förväntade häckningsutfallet är ungefär detsamma som för ensamhäckande par. Resultatet ligger i linje med vad man funnit för gråhakedoppingen, en annan vattenlevande fågelart där det finns både ensamhäckare och kolonihäckare, och där kolonihäckning kan förklaras genom en gynnsam kombination av olika miljöfaktorer.

\section{Tack}

Undersökningen har genomförts inom ramen för Projekt LOM, som på frivilligbasis utför ett rikstäckande fältarbete som syftar till att övervaka storlommens och smålommens häckning. Över åren har ekonomiska bidrag bland annat erhållits från bland annat Alvins Fond och VärldsnaturfondenWWF. Två granskare har bidragit med synpunkter och kommentarer på en tidigare textversion. 